\title{
Why was PERV not transmitted during preclinical and clinical xenotransplantation trials and after inoculation of animals?
}

\author{
Joachim Denner ${ }^{*}$
}

\begin{abstract}
Porcine endogenous retroviruses (PERVs) are present in the genome of all pigs, they infect certain human cells and therefore pose a special risk for xenotransplantation using pig cells, tissues and organs. Xenotransplantation is being developed in order to alleviate the reduced availability of human organs. Despite the fact that PERVs are able to infect certain human cells and cells from other species, transmission of PERVs has not been observed when animals (including non-human primates) were inoculated with PERV preparations or during preclinical xenotransplantations. The data indicate that PERVs were not transmitted because they were not released from the transplant or were inhibited by intracellular restriction factors and innate immunity in the recipient. In a single study in guinea pigs, a transient PERV infection and anti-PERV antibodies were described, indicating that in this case at least, the immune system may also have been involved.
\end{abstract}

\section{Xenotransplantation: the need, the problems and the progress}

Xenotransplantation using pig cells, tissues and organs is being developed in response to the steadily decreasing availability of human organs and due to an increased need by the aging human population [1]. In the US, 114,965 people are in desperate need of a lifesaving organ transplant (total waiting list candidates) and of those, 74,816 people are active waiting list candidates [2]. In contrast, only 2853 transplantations were performed in January 2018. On average, 20 people die each day while waiting for a transplant. Xenotransplantation using pig islet cells may be also the most effective solution for the treatment of diabetes. In 2015, 30.3 million Americans, or $9.4 \%$ of the population, had diabetes, among them 1.25 million American children and adults with type 1 diabetes [3]. Although type 1 diabetes can be treated with insulin, complications including limb amputations and blindness due to poor patient compliance are the main

*Correspondence: DennerJ@rki.de

Robert Koch Institute, Nordufer 20, 13353 Berlin, Germany cost factors when treating the disease. Pig islet cells producing insulin under biological regulation may therefore be the better solution.

Pigs, for several reasons including similar physiology, size, low costs as well as the ability to be cloned and easily genetically modified, are the most suitable donor animals. Pig insulin was used for decades to treat diabetes until recombinant human insulin became available. Although there are several barriers to successful clinical xenotransplantation including immunological rejection, physiological incompatibility and the risk of transmission of porcine microorganisms to the human xenotransplant recipient, significant progress has been made in recent years $[4,5]$. The problem of immunological rejection can be solved by multiple genetic modifications in the pigs and a more effective immunosuppression $[6,7]$. As a result, the recently measured survival times of pig organ transplants in non-human primates are impressive: pig islet cells can maintain insulin-independent normoglycemia for up to 950 days in diabetic monkeys [8] and the best survival time for the heterotopic transplantation of pig hearts to non-human primates has increased 
to 945 days [9]. Kidney transplantats have survived for 6-months [10-12] and a maximum survival of 90 days in orthotopic heart transplantation has been reported recently [13].

However, there is still the risk of transmission of porcine microorganisms to the human recipient. Some potentially zoonotic viruses have been well studied, and sensitive detection methods as well as elimination programs have been developed. Among these viruses are the porcine cytomegalovirus (PCMV, for review see [14, $15])$, the hepatitis E virus (HEV, for review see $[16,17])$, the porcine lymphotropic herpesviruses $[18,19]$ and the porcine circoviruses $[20,21]$. An analysis of the porcine virome revealed many other viruses [22]. PCMV was shown to reduce significantly the survival time of pig kidney transplants in non-human primates (NHP) [15, 23, 24]. HEV is a well-known zoonotic virus which can be transmitted to humans by undercooked pork meal or contact with pigs. HEV induces chronic infections in immunosuppressed patients and severe liver diseases in patients with pre-existing liver failure $[16,17]$.

\section{Porcine endogenous retroviruses (PERVs)}

Whereas most porcine viruses, bacteria and fungi can be eliminated by selection of negative animals, vaccination, treatment, early weaning, Caesarean delivery or embryo transfer, this is impossible in the case of PERVs [25-27]. PERV-A and PERV-B are integrated as DNA copies (proviruses) in the genome of all pigs and PERV$\mathrm{C}$ is found in most but not all pigs [28]. PERV-A, - B, and $-\mathrm{C}$ are gammaretroviruses, the porcine endogenous betaretroviruses are not well studied [29, 30]. PERV-A, $-\mathrm{B}$, and $-\mathrm{C}$ are closely related to the murine leukaemia virus (MuLV), the feline leukaemia virus (FeLV) and the koala retrovirus (KoRV) [28]. The related MuLV, FeLV and KoRV like many other retroviruses induce tumours and immunodeficiencies associated with opportunistic infections in the infected host (for review see [3133]). Therefore the transmission of PERV to the human xenotransplant recipient could result in tumours and/or an immunodeficiency.

Pig cells can release virus particles able to infect cells from different species including humans (Table 1) [28, 34-46]. The number of PERV proviruses is different in different pig breeds, ranging from one to over a hundred (for review see [47]. There is evidence for de novo infections and/or transpositions of PERVs in the pig, leading to different copy numbers in different organs of an individual pig [47]. In addition, recombinations between PERV-A and PERV-C have been described in pigs and such PERV-A/C recombinants are similar to PERV-A in their ability to infect human cells but were shown to have a higher replication rate compared with PERV-A [48]. PERVs-A/C were found integrated in somatic pig cells, but not in the germ line. PERV-C is an ecotropic virus infecting only pig cells.

\section{Conditions of PERV infection in cell culture}

As mentioned above, PERV-A and PERV-B are polytropic viruses able to infect human cells and cells of other species (Table 1) [28, 34-43]. To understand the risk posed by PERV it is important to analyse which cells can be infected and under which conditions and whether this infection is productive, e.g., whether the virus replicates in the infected cells.

Two multi-membrane-spanning receptors have been described for PERV-A in humans initially named human porcine endogenous retrovirus A receptor 1 and 2 (huPAR-1, huPAR-2) [49]. Two similar receptors were also found in pigs [49]. These were subsequently shown to be members of the human riboflavin transporter family, hRFT3 and hRFT1, respectively, although they have since been renamed and classified as members of the solute carrier family 52A [50]: SLC52A1 corresponds to huPAR2 and SLC522 to huPAR1. Glycosylation of huPAR2 is not necessary for the PERV-A receptor function, but three cysteines play a critical role during infection [51].

Table 1 PERV infection experiments using cultured cells of different species

\begin{tabular}{|c|c|c|}
\hline Type of infection & Species & References \\
\hline Productive infection with replication ${ }^{a}$ & Immortalised human cells (e.g., 293 cells), cat, mink & {$[28,34-39]$} \\
\hline Infection without replication ${ }^{b}$ & Primary human cells (e.g., PBMCs ${ }^{\mathrm{d}}$, PAEC), rhesus monkey, baboon, gorilla, chimpanzee ${ }^{\mathrm{d}}$ & {$[28,35,37-43]$} \\
\hline Absence of infection ${ }^{c}$ & $\begin{array}{l}\text { Mouse, rat, rabbit, cotton rat, horse, pig-tailed macaque, African green monkeys, cynomolgus } \\
\text { monkeys }\end{array}$ & {$[28,38,44-46]$} \\
\hline
\end{tabular}

\footnotetext{
a Release of more virus particles than used for infection

b Release of less virus particles than used for infection

c Absence of provirus integration

d Using human-adapted PERV
} 
HuPAR1 is fully functional as a viral receptor on human cells, but a variant receptor PAR1(109Ser-Leu) was found in NHP (baboons, rhesus monkeys, cynomolgus macaques), allowing only a limited infection $[49,52]$. Although the receptor in African green monkeys is not different from the human receptor at position 109, PERV infection is still poor. The receptor in marmosets is also equal to that of humans but it is unknown whether it is functional [53]. The receptor on murine cells is also a variant and is not functional [54]. In the case of rat cells the amount of the receptor on the cell surface is normally too low to facilitate infection, although copies increasing the receptor density by transfection rendered the cell permissive [54]. Transgenic mice expressing the human PERV-A receptor huPAR2 have been generated and after inoculation with infectious supernatant, viral DNA, RNA, protein and virus particles were detected in their organs, indicating productive viral infection [55]. However, follow-up studies showing a pathogenic effect of PERV infection have been not published.

The absence of infection in some cells can therefore be easily explained by the absence of a functional receptor $[49,52,54]$ or by a suboptimal density of the receptor on the cell surface [54]. PERV-A and PERV-B easily infect human embryonic kidney 293 cells and this is a productive infection with the virus replicating and producing excess virus particles. Other human cells such as C8166, can also be infected, although it is unclear whether the infection is productive, i.e., whether virus particles were produced, because only provirus integration was demonstrated [40]. 293 cells are immortalised cells which have been shown to express a reduced number of intracellular restriction factors such as the apolipoprotein $\mathrm{B}$ mRNA editing enzyme catalytic (APOBEC) protein family [56]. Since human primary cells contain functional restriction factors (see below) it was difficult to infect them with PERV. Infection of human PBMCs was only achieved, when human cell-adapted viruses were used [57]. Human adapted viruses had been generated either from PERV-A/C recombinants isolated from pig lymphocytes or from PERV-A by serial passage on human 293 cells. Human cell-adapted viruses are characterised by an increased replication rate and genetic modifications in the long terminal repeats $[40,46,58]$. Other human primary cells [endothelial cells, vascular fibroblast, mesangial cells and porcine aorta endothelial cells (PAEC)] were successfully infected with PERV released directly from PK-15 cells [59], a pig kidney cell line producing low amounts of PERV particles. In that report it was shown that the infection was productive, as reverse transcriptase activity was observed in the supernatant of infected cells. Recently, infection of human umbilical vein endothelial cells (HUVEC) has been reported [60], although in this case it remains unclear whether this was a productive infection, or whether only the integrated provirus or even unintegrated proviral DNA was detected by PCR.

\section{PERVs and cellular restriction factors}

As shown above, cellular restriction factors play an important role in preventing PERV infections. This is nicely demonstrated by the fact that 293 cells, which are most susceptible to PERV infection, do not express APOBEC3G. In contrast, primary cells expressing APOBEC 3G and other restriction factors are difficult to infect [57]. APOBEC proteins are cytidine deaminases that disrupt viral DNA during synthesis. These deaminases cause G-to-A hypermutation in nascent retroviral DNA strands during reverse transcription. PERV transmission from virus-producing pig PK-15 cells to human cells was significantly reduced when human APOBEC3G, but not the porcine APOBEC3G, was expressed in PK-15 cells [61]. This inhibition did not require the DNA deaminase activity of APOBEC3G. Other studies showed that both human and porcine APOBEC3 are inhibitors of PERV [62]. Porcine and human APOBEC3 (A3) could inhibit PERV replication, thereby reducing the risk of infection of human cells by PERV [63]. The replication of PERVs in cells co-expressing human APOBEC3 $\mathrm{s}$ was reduced by $60-90 \%$ compared with PERV-only control [64]. PERV-B is severely inhibited by huA3G and porcine A3Z2-Z3 (poA3F) and PERV-C infectivity was strongly inhibited by poA3Z2-Z3, which did not markedly reduce PERV-B infectivity [65]. When in addition to APOBEC3G two other major classes of retroviral restriction factors, tetherin, and TRIM5 $\alpha$, were analysed, the antiviral activity of human tetherin was slightly weaker than that of human APOBEC3G (hA3G) [66]. A combination of tetherin and hA3G was more potent than each individual restriction factor. TRIM5a is a member of the tripartite motif (TRIM) protein family involved in diverse cellular processes. Although TRIM5a is highly effective in inhibiting HIV-1 and other retroviruses, PERV-A and PERV-A/C were insensitive to restriction by TRIM5a in feline cells expressing TRIM5a from humans, African green monkeys, rhesus macaques, squirrel monkeys, rabbits or cattle [67]. Tetherin is a type I interferon-inducible molecule that blocks release of retroviruses from infected cells. Overexpression of either human or porcine tetherin on pig cells significantly reduced PERV production [68]. Another restriction factor inhibiting PERV infection of human cells is sterile alpha motif and histidine-aspartate domain 1 containing protein (SAMHD1), a cellular enzyme with phosphohydrolase activity, converting deoxynucleoside triphosphates (dNTPs) to inorganic phosphate (iPPP) and a 2'-deoxynucleoside (i.e., deoxynucleosides without a phosphate group). SAMHD1 
depletes the pool of dNTPs available to a reverse transcriptase for viral cDNA synthesis and thus prevents viral replication [69]. SAMHD1 was shown to inhibit infection of primary human monocytes, monocyte-derived dendritic cells and monocyte-derived macrophages with a human-cell adapted PERV-A/C (Al-Shehabi, H., Fiebig, U. Denner, J., Bannert N., Hofmann, H., in preparation).

Recently novel cellular restriction factors implicated in HIV-1 replication have been described [70] and it has to be analysed whether these proteins or other factors still unknown may also inhibit PERV.

\section{Absence of PERV transmission after inoculation of small laboratory animals and non-human primates}

In order to establish an animal model system to study transmission and potential pathogenic effects, PERV infection experiments in small laboratory animals as well as in NHP were performed (Table 2) [39, 41, 42, 71]. In all but one of these experiments the failure to detect viral genomes by PCR and the lack of PERV-specific antibodies indicated that no infection has occurred. In agreement with the in vitro infection data (Table 1), mice, rats and NHP could not be infected due to an incompatible receptor that only allows a limited infection or because of the low density of a functional viral receptor. The absence of antibodies in these experiments indicated that there was either no infection at all or an infection at a level insufficient to induce an antibody response. This supports the suggestion that either the virus load was too low to overcome intracellular restriction factors or that other mechanisms of innate immunity were predominantly involved in the prevention of infection. In only a single case was a transient infection observed in Guinea pigs, with provirus being detected in different organs but disappearing after 16 weeks [71]. Either tightly controlled suppression of virus replication or a potent host clearance mechanism against PERV may explain the reduced levels of viral DNA detected at later time points. The latter interpretation is supported by the durable humoral immunity observed in these animals during the timecourse of the experiment (16 weeks) [71].

\section{Absence of PERV transmission in preclinical transplantations of different pig organs into non-human primates}

In a recent review the setting and the results of seven preclinical trials involving 101 different non-human primates and transplanting pig hearts, kidneys, skin, islet cells and livers were analysed in detail (see [28]). None of the animals were infected with PERV. In the meantime, additional preclinical trials have been performed and analysed and these also show the absence of PERV transmission either by PCR or by Western blot analysis (Table 3) [53, 78-82]. However, keeping in mind, that the PERV receptor in NHP is not fully functional and the infection of NHP cells in vitro is not productive, this lack of infection in vivo is not surprising.

Table 2 PERV inoculation experiments into small animals and NHP

\begin{tabular}{|c|c|c|c|c|c|}
\hline \multirow[t]{2}{*}{ Recipient } & \multirow[t]{2}{*}{ Virus source } & \multirow{2}{*}{$\begin{array}{l}\text { Immuno-suppression, } \\
\text { treatment }\end{array}$} & \multicolumn{2}{|l|}{ PERV testing } & \multirow[t]{2}{*}{ References } \\
\hline & & & PCR analysis & Antibody detection & \\
\hline \multirow[t]{2}{*}{ SCID mice ${ }^{a}$} & Human cell-adapted PERV & None & Negative & $\mathrm{nt}$ & Irgang et al. [45] \\
\hline & $\begin{array}{l}\text { Transplantation of pig } \\
\text { PBMCs }\end{array}$ & None & Negative & $\mathrm{nt}$ & Kuddus et al. [72] \\
\hline Rats & $\begin{array}{l}\text { Supernatant PK-15 cells, } \\
\text { supernatant PERV- } \\
\text { infected } 293 \text { cells, human } \\
\text { cell-adapted PERV }\end{array}$ & $\begin{array}{l}\text { Cyclosporine A, cobra } \\
\text { venom factor }\end{array}$ & Negative & Negative & Denner et al. [73] \\
\hline Mink & $\begin{array}{l}\text { Supernatant PERV-infected } \\
293 \text { cells, human cell- } \\
\text { adapted PERV }\end{array}$ & None & Negative & Negative & Specke et al. [39] \\
\hline \multirow[t]{2}{*}{ Guinea pigs } & $\begin{array}{l}\text { Supernatant PK-15 cells, } \\
\text { supernatant PERV- } \\
\text { infected } 293 \text { cells }\end{array}$ & None & Negative & Negative & Specke et al. [44] \\
\hline & PERV-NIH & None & Transient positive & Positive & Argaw et al. [71] \\
\hline $\begin{array}{l}\text { Rhesus monkeys, pig-tailed } \\
\text { monkeys, baboons }\end{array}$ & Human cell-adapted PERV & $\begin{array}{l}\text { Cyclosporine A, everolimus } \\
\text { (RAD), methyl-predni- } \\
\text { solone }\end{array}$ & Negative & Negative & Specke et al. $[41,42]$ \\
\hline
\end{tabular}

Nt not tested

${ }^{\text {a }}$ Reports showing that SCID mice were infected with PERV $[74,75]$ were the result of an artefact based on pseudotyping between PERV and endogenous murine retroviruses $[76,77]$ 


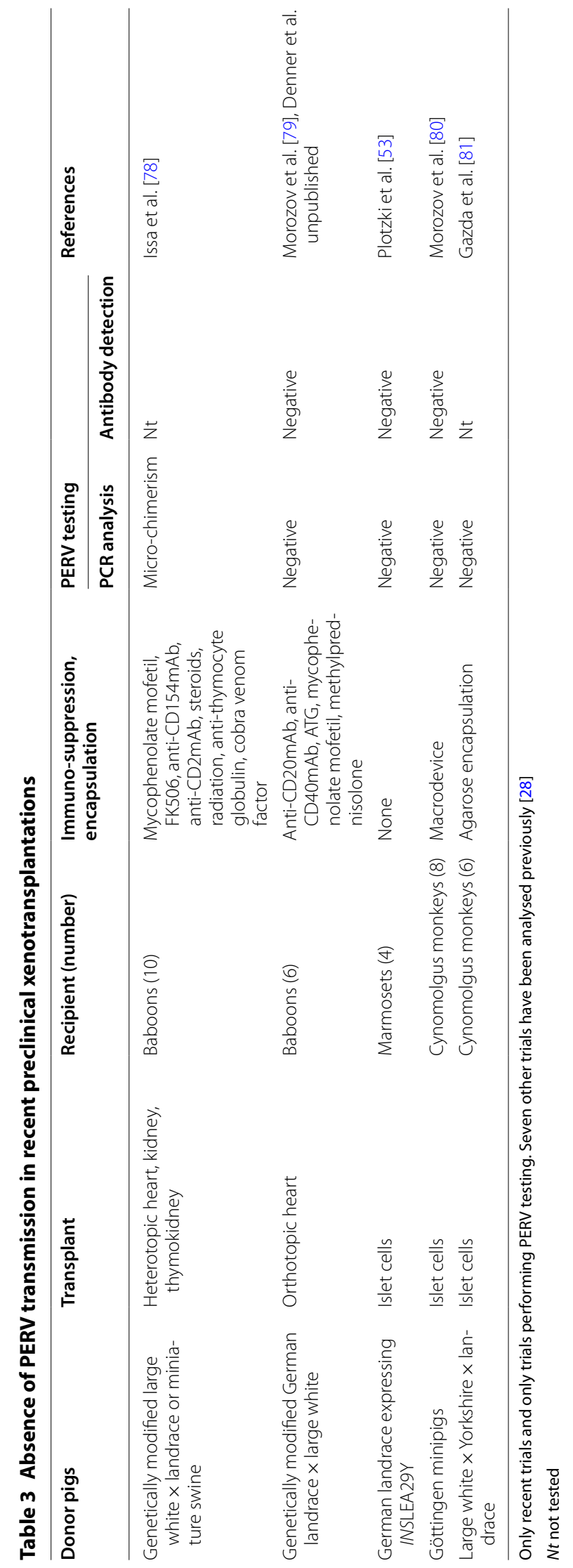




\section{Absence of PERV transmission in clinical transplantations to humans}

Several clinical trials have been performed in the past, transplanting islet cells for the treatment of diabetes, performing ex vivo perfusion using pig spleens or livers and transplanting neuronal cells (more than 200 cases, for review see [28]). PERV transmission has not been observed in any of the patients. However it is important to note, that in these trials no immunosuppression (or only a weak immunosuppression in the case of combined allogenic kidney and porcine islet cells transplantations [82]) was applied.

Recently, two clinical trials have been performed using pig islet cells to treat diabetes in humans in New Zealand and Argentina. In all cases a positive medical effect was observed [83, 84], and neither PERVs nor other porcine viruses under investigation were transmitted $[85,86]$. Islet cells from Auckland island pigs were used for these studies. These animals were well characterised [87] and had been used in a prospective preclinical trial in cynomolgus monkeys during which PERV transmission was also not observed in this trial [88]. In addition, no pharmaceutical immunosuppression was applied because the islet cells were encapsulated. It has been shown that encapsulation prevents PERV release [89] and, furthermore, there is evidence that pig islet cells do not release PERV particles [90].

\section{Conclusion and perspectives}

PERV transmission has not been observed in any of the many preclinical and clinical xenotransplantation trials performed so far, and not in any of the numerous experimental PERV infection experiments. Most of the clinical trials performed involved transplantations of pig cells, mainly encapsulated islet cells, in most cases without pharmaceutical immunosuppression. Due to the lack of functional PERV receptors in the NHP and small animal recipients, most of these experiments are not relevant for evaluating the potential risk to humans.

The risk posed by PERVs during xenotransplantation of pig tissues and organs is therefore difficult to evaluate based on these results. Transplanting vascularised large organs requires a strong immunosuppression, the organ cannot be encapsulated and usually cells of the blood and immune system will also be transmitted. Unfortunately, there is no way to definitively and reliably assess the risk posed by PERV experimentally: only long-term follow up of actual xenotransplant recipients will provide the answer.

To prevent PERV transmission after xenotransplantation, a range of different strategies have been developed, including selection of PERV-C free animals to prevent recombination between PERV-A and PERV-C [91, 92], selection of animals with a low expression of PERV-A and
PERV-B [93], generation of transgenic pigs expressing a PERV-specific small-interfering (si) RNA that reduces the expression of PERV [94-98], development of a vaccine based on neutralising antibodies against the envelope proteins of PERV [99-102] and finally gene editing to inactivate all proviral copies in the genome using either a zinc finger nuclease [103] or the CRISPR/Cas9 technology $[104,105]$.

The successful generation of live piglets in which PERVs are inactivated using the CRISPR/Cas9 technology [60] will reduce the risk of PERV transmission to zero and raises the question of whether all donor pigs used for xenotransplantation should be derived from such a stock [60, 106-108].

\section{Acknowledgements \\ The author would like to thank Dr. S. Norley, Robert Koch Institute, for critical reading of the manuscript and a fruitful discussion.}

Competing interests

The author declares that he has no competing interests.

Availability of data and materials

Not applicable.

Consent for publication

Not applicable.

Ethics approval and consent to participate

Not applicable.

Funding

The project was supported by the Deutsche Forschungsgemeinschaft, TRR127.

\section{Publisher's Note}

Springer Nature remains neutral with regard to jurisdictional claims in maps published and institutional affiliations.

Received: 24 January 2018 Accepted: 22 March 2018

Published online: 02 April 2018

References

1. Ekser B, Cooper DKC, Tector AJ. The need for xenotransplantation as a source of organs and cells for clinical transplantation. Int J Surg. 2015;23(Pt B):199-204.

2. https://unos.org/data/. Accessed 26 Mar 2018

3. http://www.diabetes.org/diabetes-basics/statistics/. Accessed $26 \mathrm{Mar}$ 2018

4. Cooper DK, Satyananda V, Ekser B, van der Windt DJ, Hara H, Ezzelarab MB, Schuurman HJ. Progress in pig-to-non-human primate transplantation models (1998-2013): a comprehensive review of the literature. Xenotransplantation. 2014;21(5):397-419.

5. Denner J. Recent progress in xenotransplantation, with emphasis on virological safety. Ann Transplant. 2016;21:717-27.

6. Niemann $\mathrm{H}$, Petersen $\mathrm{B}$. The production of multi-transgenic pigs, update and perspectives for xenotransplantation. Transgen Res. 2016:25:361-74

7. Klymiuk N, Aigner B, Brem G, Wolf E. Genetic modification of pigs as organ donors for xenotransplantation. Mol Reprod Dev. 2010:77:209-21. 
8. Shin JS, Min BH, Kim JM, Kim JS, Yoon IH, Kim HJ, Kim YH, Jang JY, Kang HJ, Lim DG, Ha J, Kim SJ, Park CG. Failure of transplantation tolerance induction by autologous regulatory $T$ cells in the pig-to-non-human primate islet xenotransplantation model. Xenotransplantation. 2016;23(4):300-9.

9. Mohiuddin MM, Singh AK, Corcoran PC, Thomas ML III, Clark T, Lewis BG, Hoyt RF, Eckhaus M, Pierson RN III, Belli AJ, Wolf E, Klymiuk N, Phelps C, Reimann KA, Ayares D, Horvath KA. Chimeric 2C10R4 anti-CD40 antibody therapy is critical for long-term survival of GTKO.hCD46.hTBM pig-to-primate cardiac xenograft. Nat Commun. 2016;7:11138.

10. Higginbotham L, Mathews D, Breeden CA, Song M, Farris AB 3rd, Larsen CP, Ford ML, Lutz AJ, Tector M, Newell KA, Tector AJ, Adams AB. Pretransplant antibody screening and anti-CD154 costimulation blockade promote long-term xenograft survival in a pig-to-primate kidney transplant model. Xenotransplantation. 2015;22(3):221-30.

11. Iwase H, Liu H, Wijkstrom M, Zhou H, Singh J, Hara H, Ezzelarab M, Long C, Klein E, Wagner R, Phelps C, Ayares D, Shapiro R, Humar A, Cooper DK. Pig kidney graft survival in a baboon for 136 days: longest life-supporting organ graft survival to date. Xenotransplantation. 2015;22(4):302-9.

12. Tanabe T, Watanabe H, Shah JA, Sahara H, Shimizu A, Nomura S, Asfour A, Danton M, Boyd L, Dardenne Meyers A, Ekanayake-Alper DK, Sachs $\mathrm{DH}$, Yamada K. Role of intrinsic (graft) versus extrinsic (host) factors in the growth of transplanted organs following allogeneic and xenogeneic transplantation. Am J Transplant. 2017. https://doi.org/10.1111/ ajt.14210.

13. http://www.sciencemag.org/news/2017/09/scientists-grow-bullishpig-human-transplants. https://doi.org/10.1126/science.aaq0311. Accessed 26 Mar 2018

14. Mueller NJ, Fishman JA. Herpesvirus infections in xenotransplantation: pathogenesis and approaches. Xenotransplantation. 2004;11(6):486-90.

15. Denner J. Xenotransplantation and porcine cytomegalovirus. Xenotransplantation. 2015;22:329-35.

16. Widén F. Hepatitis E as a zoonosis. Adv Exp Med Biol. 2016;948:61-71.

17. Denner J. Xenotransplantation and hepatitis E virus. Xenotransplantation. 2015;22(3):167-73.

18. Denner J, Mueller NJ. Preventing transfer of infectious agents. Int J Surg. 2015;23:306-11.

19. Meng XJ. Emerging and re-emerging swine viruses. Transbound Emerg Dis. 2012;59(Suppl 1):85-102.

20. Finsterbusch T, Mankertz A. Porcine circoviruses—small but powerful. Virus Res. 2009;143(2):177-83.

21. Denner J, Mankertz A. Porcine circoviruses and xenotransplantation. Viruses. 2017;20(9):4.

22. Denner J. The porcine virome and xenotransplantation. Virol f 2017;14(1):17.

23. Yamada K, Tasaki M, Sekijima M, Wilkinson RA, Villani V, Moran SG, et al. Porcine cytomegalovirus infection is associated with early rejection of kidney grafts in a pig to baboon xenotransplantation model. Transplantation. 2014;98:411-7.

24. Sekijima M, Waki S, Sahara H, Tasaki M, Wilkinson RA, Villani V, et al. Results of life-supporting galactosyltransferase knockout kidneys in cynomolgus monkeys using two different sources of galactosyltransferase knockout swine. Transplantation. 2014;98:419-4126.

25. Fishman JA, Patience C. Xenotransplantation, infectious risk revisited. Am J Transplant. 2004:4:1383-90.

26. Wilson CA. Porcine endogenous retroviruses and xenotransplantation. Cell Mol Life Sci. 2008:65(21):3399-412.

27. Scobie $L$, Takeuchi Y. Porcine endogenous retrovirus and other viruses in xenotransplantation. Curr Opin Organ Transplant. 2009:14(2):175-9.

28. Denner J, Tönjes RR. Infection barriers to successful xenotransplantation focusing on porcine endogenous retroviruses. Clin Microbiol Rev. 2012;25(2):318-43.

29. Patience C, Switzer WM, Takeuchi Y, Griffiths DJ, Goward ME, Heneine W, Stoye JP, Weiss RA. Multiple groups of novel retroviral genomes in pigs and related species. J Virol. 2001;75(6):2771-5.

30. Ericsson T, Oldmixon B, Blomberg J, Rosa M, Patience C, Andersson G. Identification of novel porcine endogenous betaretrovirus sequences in miniature swine. J Virol. 2001;75(6):2765-70.

31. Rosenberg N, Jolicoeur P. Retroviral pathogenesis. In: Coffin JM, Hughes $\mathrm{SH}$, Varmus HE, editors. Retroviruses, chapter 10. Cold Spring Harbor: Cold Spring Harbor Laboratory Press; 1997
32. Hartmann K. Clinical aspects of feline retroviruses: a review. Viruses. 2012;4(11):2684-710.

33. Denner J, Young PR. Koala retroviruses: characterization and impact on the life of koalas. Retrovirology. 2013;10:108.

34. Patience $C$, Takeuchi Y, Weiss RA. Infection of human cells by an endogenous retrovirus of pigs. Nat Med. 1997;3:282-6.

35. Specke V, Rubant S, Denner J. Productive infection of human primary cells and cell lines with porcine endogenous retroviruses. Virology. 2001;285(2):177-80

36. Wilson CA, Wong S, Muller J, Davidson CE, Rose TM, Burd P. Type C retrovirus released from porcine primary peripheral blood mononuclear cells infects human cells. JVirol. 1998;72(4):3082-7.

37. Blusch JH, Patience C, Takeuchi Y, Templin C, Roos C, Von Der Helm K, Steinhoff G, Martin U. Infection of nonhuman primate cells by pig endogenous retrovirus. J Virol. 2000;74(16):7687-90.

38. Takeuchi Y, Patience C, Magre S, Weiss RA, Banerjee PT, Le Tissier P, Stoye JP. Host range and interference studies of three classes of pig endogenous retrovirus. J Virol. 1998;72(12):9986-91.

39. Specke V, Plesker R, Coulibaly C, Boller K, Denner J. Productive infection of a mink cell line with porcine endogenous retroviruses (PERVs) but lack of transmission to minks in vivo. Arch Virol. 2002;147(2):305-19.

40. Karlas A, Irgang M, Votteler J, Specke V, Ozel M, Kurth R, Denner J. Characterisation of a human cell-adapted porcine endogenous retrovirus PERV-A/C. Ann Transplant. 2010;15(2):45-54.

41. Specke V, Schuurman HJ, Plesker R, Coulibaly C, Ozel M, Langford G, Kurth $R$, Denner J. Virus safety in xenotransplantation: first exploratory in vivo studies in small laboratory animals and non-human primates. Transpl Immunol. 2002;9(2-4):281-8.

42. Specke V, Plesker R, Wood J, Coulibaly C, Suling K, Patience C, Kurth R, Schuurman HJ, Denner J. No in vivo infection of triple immunosuppressed non-human primates after inoculation with high titers of porcine endogenous retroviruses. Xenotransplantation. 2009;16(1):34-44.

43. Ritzhaupt A, Van Der Laan LJ, Salomon DR, Wilson CA. Porcine endogenous retrovirus infects but does not replicate in nonhuman primate primary cells and cell lines. J Virol. 2002;76(22):11312-20.

44. Specke V, Tacke SJ, Boller K, Schwendemann J, Denner J. Porcine endogenous retroviruses: in vitro host range and attempts to establish small animal models. J Gen Virol. 2001;82(Pt 4):837-44.

45. Irgang M, Karlas A, Laue C, Specke V, Tacke SJ, Kurth R, Schrezenmeir J, Denner J. Porcine endogenous retroviruses PERV-A and PERV-B infect neither mouse cells in vitro nor SCID mice in vivo. Intervirology. 2005:48(2-3):167-73.

46. Wilson CA, Wong S, VanBrocklin M, Federspiel MJ. Extended analysis of the in vitro tropism of porcine endogenous retrovirus. J Virol. 2000;74(1):49-56

47. Denner J. How active are porcine endogenous retroviruses (PERVs)? Viruses. 2016;8(8):215. https://doi.org/10.3390/v8080215.

48. Denner J. Recombinant porcine endogenous retroviruses (PERV-A/C): a new risk for xenotransplantation? Arch Virol. 2008;153(8):1421-6.

49. Ericsson TA, Takeuchi Y, Templin C, Quinn G, Farhadian SF, Wood JC, Oldmixon BA, Suling KM, Ishii JK, Kitagawa Y, Miyazawa T, Salomon DR, Weiss RA, Patience C. Identification of receptors for pig endogenous retrovirus. Proc Natl Acad Sci USA. 2003:100(11):6759-64.

50. Yonezawa A, Inui K. Novel riboflavin transporter family RFVT/SLC52: identification, nomenclature, functional characterization and genetic diseases of RFVT/SLC52. Mol Asp Med. 2013;34(2-3):693-701.

51. Colon-Moran W, Argaw T, Wilson CA. Three cysteine residues of SLC52A1, a receptor for the porcine endogenous retrovirus-A (PERV-A), play a critical role in cell surface expression and infectivity. Virology. 2017:507:140-50

52. Mattiuzzo G, Takeuchi Y. Suboptimal porcine endogenous retrovirus infection in non-human primate cells: implication for preclinical xenotransplantation. PLOS ONE. 2010;5(10):e13203.

53. Plotzki E, Wolf-van Buerck L, Knauf Y, Becker T, Maetz-Rensing K, Schuster M, Baehr A, Klymiuk N, Wolf E, Seissler J, Denner J. Virus safety of islet cell transplantation from transgenic pigs to marmosets. Virus Res. 2015;204:95-102

54. Mattiuzzo G, Matouskova M, Takeuchi Y. Differential resistance to cell entry by porcine endogenous retrovirus subgroup $A$ in rodent species. Retrovirology. 2007;4:93 
55. Martina Y, Marcucci KT, Cherqui S, Szabo A, Drysdale T, Srinivisan U, Wilson CA, Patience C, Salomon DR. Mice transgenic for a human porcine endogenous retrovirus receptor are susceptible to productive viral infection. J Virol. 2006;80(7):3135-46.

56. Piroozmand A, Yamamoto Y, Khamsri B, Fujita M, Uchiyama T, Adachi A Generation and characterization of APOBEC3G-positive 293T cells for HIV-1 Vif study. J Med Invest. 2007;54(1-2):154-8.

57. Denner J. Porcine endogenous retrovirus infection of human peripheral blood mononuclear cells. Xenotransplantation. 2015;22(2):151-2.

58. Denner J, Specke V, Thiesen U, Karlas A, Kurth R. Genetic alterations of the long terminal repeat of an ecotropic porcine endogenous retrovirus during passage in human cells. Virology. 2003;314(1):125-33.

59. Martin U, Winkler ME, Id M, Radeke H, Arseniev L, Takeuchi Y, Simon AR, Patience C, Haverich A, Steinhoff G. Productive infection of primary human endothelial cells by pig endogenous retrovirus (PERV). Xenotransplantation. 2000;7(2):138-42.

60. Güell M, Niu D, Kan Y, George H, Wang T, Lee IH, Wang G, Church G, Yang L. PERV inactivation is necessary to guarantee absence of pig-topatient PERVs transmission in xenotransplantation. Xenotransplantation. 2017. https://doi.org/10.1111/xen.12366.

61. Jónsson SR, LaRue RS, Stenglein MD, Fahrenkrug SC, Andrésdóttir V, Harris RS. The restriction of zoonotic PERV transmission by human APOBEC3G. PLOS ONE. 2007;2(9):e893.

62. Dörrschuck E, Münk C, Tönjes RR. APOBEC3 proteins and porcine endogenous retroviruses. Transplant Proc. 2008;40(4):959-61.

63. Dörrschuck E, Fischer N, Bravo IG, Hanschmann KM, Kuiper H, Spötter A Möller R, Cichutek K, Münk C, Tönjes RR. Restriction of porcine endogenous retrovirus by porcine APOBEC3 cytidine deaminases. J Virol. 2011;85(8):3842-57.

64. Lee J, Choi JY, Lee HJ, Kim KC, Choi BS, Oh YK, Kim YB. Repression of porcine endogenous retrovirus infection by human APOBEC3 proteins. Biochem Biophys Res Commun. 2011;407(1):266-70.

65. Park SH, Kim JH, Jung YT. Differential sensitivity of porcine endogenous retrovirus to APOBEC3-mediated inhibition. Arch Virol. 2015;160(8):1901-8.

66. Bae EH, Jung YT. Comparison of the effects of retroviral restriction factors involved in resistance to porcine endogenous retrovirus. J Microbiol Biotechnol. 2014;24(4):577-83.

67. Wood A, Webb BL, Bartosch B, Schaller T, Takeuchi Y, Towers GJ. Porcine endogenous retroviruses PERV $A$ and $A / C$ recombinant are insensitive to a range of divergent mammalian TRIM5alpha proteins including human TRIM5alpha. J Gen Virol. 2009;90(Pt 3):702-9.

68. Mattiuzzo G, Ivol S, Takeuchi Y. Regulation of porcine endogenous retrovirus release by porcine and human tetherins. J Virol. 2010;84(5):2618-22.

69. Goldstone DC, Ennis-Adeniran V, Hedden JJ, Groom HC, Rice Gl, Christodoulou E, Walker PA, Kelly G, Haire LF, Yap MW, de Carvalho LP, Stoye JP, Crow YJ, Taylor IA, Webb M. HIV-1 restriction factor SAMHD1 is a deoxynucleoside triphosphate triphosphohydrolase. Nature. 2011:480(7377):379-82.

70. Ghimire D, Rai M, Gaur R. Novel host restriction factors implicated in HIV-1 replication. J Gen Virol. 2018. https://doi.org/10.1099/ jgv.0.001026.

71. Argaw T, Colon-Moran W, Wilson CA. Limited infection without evidence of replication by porcine endogenous retrovirus in guinea pigs. $J$ Gen Virol. 2004;85(Pt 1):15-9.

72. Kuddus RH, Metes DM, Nalesnik MA, Logar AJ, Rao AS, Fung JJ. Porcine cell microchimerism but lack of productive porcine endogenous retrovirus (PERV) infection in naive and humanized SCID-beige mice treated with porcine peripheral blood mononuclear cells. Transpl Immunol. 2004;13(1):15-24.

73. Denner J, Specke V, Karlas A, Chodnevskaja I, Meyer T, Moskalenko V, Kurth R, Ulrichs K. No transmission of porcine endogenous retroviruses (PERVs) in a long-term pig to rat xenotransplantation model and no infection of immunosuppressed rats. Ann Transplant. 2008;13(1):20-31.

74. van der Laan LJ, Lockey C, Griffeth BC, Frasier FS, Wilson CA, Onions DE, Hering BJ, Long Z, Otto E, Torbett BE, Salomon DR. Infection by porcine endogenous retrovirus after islet xenotransplantation in SCID mice. Nature. 2000;407(6800):90-4.

75. Deng YM, Tuch BE, Rawlinson WD. Transmission of porcine endogenous retroviruses in severe combined immunodeficient mice xenotransplanted with fetal porcine pancreatic cells. Transplantation. 2000;70(7):1010-6.

76. Yang YG, Wood JC, Lan P, Wilkinson RA, Sykes M, Fishman JA, Patience C. Mouse retrovirus mediates porcine endogenous retrovirus transmission into human cells in long-term human-porcine chimeric mice. J Clin Invest. 2004;114(5):695-700.

77. Martina Y, Kurian S, Cherqui S, Evanoff G, Wilson C, Salomon DR. Pseudotyping of porcine endogenous retrovirus by xenotropic murine leukemia virus in a pig islet xenotransplantation model. Am J Transplant. 2005;5(8):1837-47.

78. Issa NC, Wilkinson RA, Griesemer A, Cooper DK, Yamada K, Sachs DH, Fishman JA. Absence of replication of porcine endogenous retrovirus and porcine lymphotropic herpesvirus type 1 with prolonged pig cell microchimerism after pig-to-baboon xenotransplantation. J Virol. 2008;82(24):12441-8

79. Morozov VA, Abicht JM, Reichart B, Mayr T, Guethoff S, Denner J. Active replication of porcine cytomegalovirus (PCMV) following transplantation of a pig heart into a baboon despite undetected virus in the donor pig. Ann Virol Res. 2016;2(3):1018.

80. Morozov VA, Ludwig S, Ludwig B, Rotem A, Barkai U, Bornstein SR, Denner J. Islet cell transplantation from Göttingen minipigs to cynomolgus monkeys: analysis of virus safety. Xenotransplantation. 2016;23(4):320-7.

81. Gazda LS, Collins J, Lovatt A, Holdcraft RW, Morin MJ, Galbraith D, Graham M, Laramore MA, Maclean C, Black J, Milne EW, Marthaler DG, Vinerean HV, Michalak MM, Hoffer D, Richter S, Hall RD, Smith BH. A comprehensive microbiological safety approach for agarose encapsulated porcine islets intended for clinical trials. Xenotransplantation. 2016;23(6):444-63.

82. Groth CG, Korsgren O, Tibell A, Tollemar J, Möller E, Bolinder J, Ostman J, Reinholt FP, Hellerström C, Andersson A. Transplantation of porcine fetal pancreas to diabetic patients. Lancet. 1994;344(8934):1402-4.

83. Matsumoto S, Abalovich A, Wechsler C, Wynyard S, Elliott RB. Clinical benefit of islet xenotransplantation for the treatment of type 1 diabetes. EBioMedicine. 2016;12:255-62.

84. Cooper DK, Matsumoto S, Abalovich A, Itoh T, Mourad NI, Gianello PR, Wolf E, Cozzi E. Progress in clinical encapsulated islet xenotransplantation. Transplantation. 2016;100(11):2301-8.

85. Wynyard S, Nathu D, Garkavenko O, Denner J, Elliott R. Microbiological safety of the first clinical pig islet xenotransplantation trial in New Zealand. Xenotransplantation. 2014;21(4):309-23.

86. Morozov VA, Wynyard S, Matsumoto S, Abalovich A, Denner J, Elliott R. No PERV transmission during a clinical trial of pig islet cell transplantation. Virus Res. 2017:227:34-40.

87. Garkavenko O, Wynyard S, Nathu D, Simond D, Muzina M, Muzina Z, Scobie L, Hector RD, Croxson MC, Tan P, Elliott BR. Porcine endogenous retrovirus (PERV) and its transmission characteristics: a study of the New Zealand designated pathogen-free herd. Cell Transplant. 2008;17(12):1381-8

88. Garkavenko O, Dieckhoff B, Wynyard S, Denner J, Elliott RB, Tan PL, Croxson MC. Absence of transmission of potentially xenotic viruses in a prospective pig to primate islet xenotransplantation study. J Med Virol. 2008:80(11):2046-52

89. Petersen P, Lembert N, Zschocke P, Stenglein S, Planck H, Ammon HP, Becker HD. Hydroxymethylated polysulphone for islet macroencapsulation allows rapid diffusion of insulin but retains PERV. Transplant Proc. 2002;34:194-5.

90. Irgang M, Laue C, Velten F, Kurth R, Schrezenmeier J, Denner J. No evidence for PERV release by islet cells from German landrace pigs. Ann Transplant. 2008;13(4):59-66.

91. Kaulitz D, Mihica D, Adlhoch C, Semaan M, Denner J. Improved pig donor screening including newly identified variants of porcine endogenous retrovirus-C (PERV-C). Arch Virol. 2013;158(2):341-8.

92. Kaulitz D, Mihica D, Dorna J, Costa MR, Petersen B, Niemann H, Tönjes RR, Denner J. Development of sensitive methods for detection of porcine endogenous retrovirus-C (PERV-C) in the genome of pigs. J Virol Methods. 2011;175(1):60-5.

93. Dieckhoff B, Kessler B, Jobst D, Kues W, Petersen B, Pfeifer A, Kurth R, Niemann H, Wolf E, Denner J. Distribution and expression of porcine endogenous retroviruses in multi-transgenic pigs generated for xenotransplantation. Xenotransplantation. 2009;16(2):64-73. 
94. Ramsoondar J, Vaught T, Ball S, Mendicino M, Monahan J, Jobst P, Vance A, Duncan J, Wells K, Ayares D. Production of transgenic pigs that express porcine endogenous retrovirus small interfering RNAs. Xenotransplantation. 2009;16(3):164-80.

95. Karlas A, Kurth R, Denner J. Inhibition of porcine endogenous retroviruses by RNA interference: increasing the safety of xenotransplantation. Virology. 2004;325(1):18-23.

96. Dieckhoff B, Karlas A, Hofmann A, Kues WA, Petersen B, Pfeifer A, Niemann $H$, Kurth $R$, Denner J. Inhibition of porcine endogenous retroviruses (PERVs) in primary porcine cells by RNA interference using lentiviral vectors. Arch Virol. 2007;152(3):629-34.

97. Dieckhoff B, Petersen B, Kues WA, Kurth R, Niemann H, Denner J. Knockdown of porcine endogenous retrovirus (PERV) expression by PERV-specific shRNA in transgenic pigs. Xenotransplantation. 2008;15(1):36-45.

98. Semaan M, Kaulitz D, Petersen B, Niemann H, Denner J. Long-term effects of PERV-specific RNA interference in transgenic pigs. Xenotransplantation. 2012;19(2):112-21.

99. Kaulitz D, Fiebig U, Eschricht M, Wurzbacher C, Kurth R, Denner J. Generation of neutralising antibodies against porcine endogenous retroviruses (PERVs). Virology. 2011;411(1):78-86.

100. Denner J, Mihica D, Kaulitz D, Schmidt CM. Increased titers of neutralizing antibodies after immunization with both envelope proteins of the porcine endogenous retroviruses (PERVs). Virol J. 2012;9:260.

101. Waechter A, Eschricht M, Denner J. Neutralization of porcine endogenous retrovirus by antibodies against the membrane-proximal external region of the transmembrane envelope protein. J Gen Virol. 2013;94(Pt 3):643-51.

102. Waechter A, Denner J. Novel neutralising antibodies targeting the $\mathrm{N}$-terminal helical region of the transmembrane envelope protein p15E of the porcine endogenous retrovirus (PERV). Immunol Res. 2014;58(1):9-19.

103. Semaan M, Ivanusic D, Denner J. Cytotoxic effects during knock out of multiple porcine endogenous retrovirus (PERV) sequences in the pig genome by zinc finger nucleases (ZFN). PLOS ONE. 2015;10(4):e0122059.

104. Yang L, Güell M, Niu D, George H, Lesha E, Grishin D, Aach J, Shrock E, Xu W, Poci J, Cortazio R, Wilkinson RA, Fishman JA, Church G. Genomewide inactivation of porcine endogenous retroviruses (PERVs). Science. 2015;350(6264):1101-4

105. Niu D, Wei HJ, Lin L, George H, Wang T, Lee $H$, Zhao HY, Wang Y, Kan Y, Shrock E, Lesha E, Wang G, Luo Y, Qing Y, Jiao D, Zhao H, Zhou X, Wang S, Wei H, Güell M, Church GM. Yang L Inactivation of porcine endogenous retrovirus in pigs using CRISPR-Cas9. Science. 2017;357(6357):1303-7.

106. Denner J. Paving the path toward porcine organs for transplantation. N Engl J Med. 2017;377(19):1891-3.

107. Scobie L, Denner J, Schuurman HJ. Inactivation of porcine endogenous retrovirus in pigs using CRISPR-Cas9, editorial commentary. Xenotransplantation. 2017. https://doi.org/10.1111/xen.12363.

108. Denner J. Advances in organ transplant from pigs. Science. 2017:357(6357):1238-9.

\section{Submit your next manuscript to BioMed Central and we will help you at every step:}

- We accept pre-submission inquiries

- Our selector tool helps you to find the most relevant journal

- We provide round the clock customer support

- Convenient online submission

- Thorough peer review

- Inclusion in PubMed and all major indexing services

- Maximum visibility for your research

Submit your manuscript at www.biomedcentral.com/submit 